\title{
Peran Ayah Dalam Problematika Emosi Anak Usia Dini
}

\author{
Amining \\ STKIP Modern Ngawi \\ J1. Ir. Soekarno (Ring Road Barat) Kabupaten Ngawi \\ aminingafit7276@gmail.com \\ Sri Harti Nur Azizah \\ STKIP Modern Ngawi \\ Jl. Ir. Soekarno (Ring Road Barat) Kabupaten Ngawi \\ srihartinurazizah@gmail.com
}

\begin{abstract}
Abstrak
Kecerdasan emosi anak usia dini adalah kemampuan untuk mengenali, mengolah, dan mengontrol emosi agar anak mampu merespon secara positif setiap kondisi yang merangsang munculnya emosi-emosi. Dengan mengajari anak-anak keterampilan emosi anak-anak akan lebih mampu mengatasi berbagai masalah yang timbul selama proses perkembangannya menuju manusia dewasa. Penelitian ini bertujuan mengetahui mengetahui apa penyebab emosional yang sering muncul pada diri anak dan apakah emosional anak yamg berlebihan dapat dicegah sejak dini. Dalam penelitian ini, tim peneliti menggunakan metode penelitian kualitatif dengan menggunakan observasi, dokumentasi, dan wawancara. Penelitian ini dapat menjadikan wawasan bahwa pentingnya peran seorang ayah akan mempengaruhi perkembangan emosi anak. Karena dengan adanya peran seorang ayah anak akan merasa senang, sehinnga yang ditimbulkan adalah emosi positif. Hasil penelitian menunjukkan bahwa emosi secara berlebih (emosi negatif) pada anak tersebut disebabkan oleh kurangnya kasih sayang seorang ayah.
\end{abstract}

Kata kunci: Problematik, Emosi, Peran Ayah

\section{PENDAHULUAN}

Pada umumnya anak terutama anak usia dini memang memiliki kecenderungan lebih emosional daripada orang dewasa, karena masih memiliki sedikit kemampuan untuk mengendalikan dorongan hatinya. Anak usia dini juga mudah putus asa dikarenakan belum dapat mengungkapkan dirinya secara emosional. Karena itulah bimbingan orang dekat mengenai pengenalan emosi dalam diri sangat diperlukan, juga untuk memberi contoh sikap dan pengelolaan emosi yang tepat. Setiap anak berbeda dengan lainnya., maka dari itu diperlukan kepekaan orang tua untuk membimbing anak melalui perkembangan emosionalnya. Bimbingan merupakan pemberian bantuan kepada setiap orang yang dilakukan oleh ahli dalam bidang bimbingan, dan diharapkan dengan bimbingan tersebut orang yang diberikan bimbingan dapat berkembang sesuai dengan kemampuannya (Marsudi,2003:31).

Penelitian ini dilakukan karena menurut observasi yang dilakukan oleh peneliti anak cenderung memiliki emosi yang tinggi. Pada waktu pembelajaran, emosi anak sering muncul, misalnya pada waktu mengerjakan tugas yang diberikan oleh ibu guru, anak tiba-tiba membuang alat tulis yang digunakan sebagai alat pembelajaran. Hal ini sering dilakukan anak tanpa mempedulikan keadaan 
sekitarnya. Anak juga menangis sambil teriak-teriak penuh dengan kemarahan, dan juga tidak segan-segan untuk menyakiti orang di sekitarnya. Tujuan Penelitian peneliti ingin mengetahui apa penyebab emosional yang sering muncul pada diri anak. Peneliti ingin mengetahui apakah emosional anak yamg berlebihan dapat dicegah sejak dini. Kegunaan penelitian bagi guru dapat dijadikan solusi apa bila di lembaga terdapat anak yang memiliki emosi yang tidak terkendali. Bagi peneliti, dapat mengetahui upaya-upaya yang dilakukan untuk mengatasi gangguan emosional yang tinggi. Bagi orang tua dapat menambah pengetahuan orang tua dalam mengatasi emosional anak usia dini.

\section{KAJIAN PUSTAKA}

Inteligensi atau kecerdasan dapat didefinisikan melalui dua jalan yaitu secara kuantitatif adalah proses belajar untuk memecahkan masalah yang dapat diukur dengan tes inteligensi, dan secara kualitatif suatu cara berpikir dalam membentuk konstruk bagaimana menghubungkan dan mengelola informasi dari luar yang disesuaikan dengan dirinya (Casmini,2007:14). Kecerdasan adalah kemampuan untuk memecahkan atau menciptakan sesuatu yang bernilai bagi budaya tertentu (Efendi, 2005:81). Kecerdasan sebagai suatu kapasitas umum dari individu untuk bertindak, berpikir rasional dan berinteraksi dengan lingkungan secara efektif (Syaiful Sagala, 2010: 82). Sehingga dapat diartikan pula bahwa kecerdasan atau Intelligensi adalah kemampuan untuk menguasai kemampuan tertentu.

Emosi pada dasarnya adalah dorongan untuk bertindak, rencana seketika untuk mengatasi masalah yang telah ditanamkan secara berangsur-angsur oleh evolusi (Goleman 2005: 7). Akar kata emosi adalah movere, kata kerja dalam Bahasa Latin adalah menggerakkan atau bergerak. Kecenderungan bergerak merupakan hal mutlak dalam emosi. Emosi memancing tindakan, emosi menjadi akar dorongan untuk bertindak terpisah dari reaksi-reaksi yang tampak di mata. Dalam Kamus Besar Bahasa Indonesia emosi di definisikan sebagai (1) luapan perasaan yang berkembang dan surut dalam waktu singkat (2) keadaan dan reaksi psikologis dan fisiologis. Emosi adalah suatu reaksi tubuh menghadapi situasi tertentu. Sifat dan intensitas emosi biasanya terkait erat dengan aktivitas kognitif (berpikir) manusia sebagai hasil persepsi terhadap situasi J.P Du Preez (Anthony Dio Martin, 2003: 91). Emosi adalah hasil reaksi kognitif terhadap situasi spesifik.Emosi adalah suatu perasaan dan pikiran-pikiran khas, suatu keadaan biologis dan psikologis, serta serangkaian kecenderungan untuk bertindak (Efendi, 2005: 176). Dari beberapa pendapat para ahli dapat diperoleh kesimpulan bahwa emosi adalah suatu keadaan gejolak jiwa yang berhubungan dengan pikiran dan perasaan yang meliputi rasa senang, cinta, terharu, sedih, marah, cemburu, cemas, takut, panik dan sebagainya. Istilah kecerdasan emosional pertama kali dilontarkan tahun 1990 oleh psikolog Peter Salovey dari Harvard University dan John Mayer dari University of New Hampshire untuk menerangkan kualitas-kualitas emosional yang tampaknya penting bagi keberhasilan. Kualitas-kualitas ini antara lain adalah; Empati, mengungkapkan dan memahami perasaan, mengendalikan amarah, kemandirian, kemampuan menyesuaikan diri, disukai, kemampuan memecahkan masalah antarpribadi, 
ketekunan, kesetiakawanan, keramahan, dan sikap hormat (Shapiro, 2001). Kecerdasan emosional atau yang sering disebut EQ sebagai himpunan bagian dari kecerdasan sosial yang melibatkan kemampuan memantau perasaan sosial yang melibatkan kemampuan pada orang lain, memilah-milah semuanya dan menggunakan informasi ini untuk membimbing pikiran dan tindakan. Kecerdasan emosional sangat dipengaruhi oleh lingkungan, tidak bersifat menetap, dapat berubah-ubah setiap saat. Untuk itu, peranan lingkungan terutama orangtua pada masa kanak-kanak sangat mempengaruhi dalam pembentukan kecerdasan emosional (Bahtiar, 2009).

Kecerdasan emosional adalah kemampuan seseorang mengatur kehidupan emosinya dengan inteligensi (to manage our emotional life with intelligence), menjaga keselarasan emosi dan pengungkapannya (the appropriateness of emotion and its expression) melalui keterampilan kesadaran diri, pengendalian diri, motivasi diri, empati, dan keterampilan sosial (Bahtiar, 2009). Sedangkan kecerdasan emosi anak usia dini adalah kemampuan untuk mengenali, mengolah, dan mengontrol emosi agar anak mampu merespon secara positif setiap kondisi yang merangsang munculnya emosi-emosi. Dengan mengajari anak-anak keterampilan emosi anak-anak akan lebih mampu mengatasi berbagai masalah yang timbul selama proses perkembangannya menuju manusia dewasa. Dari beberapa penelitian dalam bidang psikologi anak telah membuktikan bahwa anak-anak yang memiliki kecerdasan emosi yang tinggi adalah anakanak yang bahagia, percaya diri, populer, dan lebih sukses di sekolah (Mashar, 2011). Emosi dapat diartikan sebagai perasaan individu, baik berupa perasaan positif maupun perasaan negatif sebagai respon terhadap suatu keadaan yang melingkupinya akibat dari adanya hubungan antara dirinya dengan individu lainnya dan dengan suatu kelompok. Jadi, perkembangan emosi anak usia dini dapat didefinisikan sebagai perubahan perasaan positif maupun negatif pada anak usia 0-6 tahun sebagai akibat dari adanya hubungan antara dirinya dan orang lain (Wiyani, 2014).

Emotional intelligence may be developed by education that focuses on helping children develop basic emotional intelligence abilities such as expressing, understanding, and managing emotions and using these skills to cope with everyday social problems (Ulutas \& Omeroglu, 2007). Hal ini menjelaskan bahwa kecerdasan emosional dapat dikembangkan oleh pendidikan yang berfokus untuk membantu anak-anak mengembangkan kemampuan kecerdasan emosi dasar seperti mengungkapkan, memahami, dan mengelola emosi dan menggunakan keterampilan ini untuk mengatasi masalah sosial dalam seharihari. Sementara itu, terdapat tujuh unsur utama pada kecerdasan emosional anak usia dini, yakni (Wiyani, 2014):

a. Keyakinan, merupakan perasaan kendali dan penguasaan seorang anak terhadap tubuh, perilaku dan dunia, serta perasaan anak bahwa anak lebih cenderung berhasil daripada tidak dalam apa yang dikerjakannya, dan bahwa orang-orang dewasa akan bersedia menolongnya.

b. Rasa ingin tahu, merupakan perasaan bahwa menyelidiki segala sesuatu itu bersifat positif dan menimbulkan kesenangan. 
c. Niat, merupakan menggambarkan hasrat dan kemampuan untuk berhasil dan untuk bertindak berdasarkan niat itu dengan tekun.

d. Kendali diri, merupakan kemampuan untuk menyesuaikan dan mengendalikan tindakan dengan pola yang sesuai dengan usia, dan merupakan suatu rasa kendali batiniah.

e. Keterkaitan, merupakan kemampuan untuk melibatkan diri dengan orang lain berdasarkan pada perasaan saling memahami.

f. Kecakapan berkomunikasi, merupakan keyakinan dan kemampuan verbal untuk bertukar gagasan, perasaan dan konsep dengan orang lain. Kemampuan ini memiliki keterkaitan dengan rasa percaya pada orang lain, kenyamanan terlibat dengan orang lain, termasuk dengan orang dewasa.

g. Kooperatif, merupakan kemampuan untuk menyeimbangkan kebutuhannya sendiri dengan kebutuhan orang lain dalam kegiatan kelompok.

Dari beberapa pengertian di atas dapat disimpulkan bahwa kecerdasan emosi adalah kecakapan emosional meliputi kemampuan mengenali emosi diri sendiri dan orang lain, membedakan jenis emosi dan menggunakannya untuk mengarahkan pikiran dan perilakunya sendiri. Semakin cerdas kondisi emosional pada diri individu maka semakin dapat mengenali emosi diri, mengelola emosinya sendiri, memotivasi dirinya sendiri, berempati dan membina hubungan dengan orang lain.

\section{METODE}

Penelitian ini menggunakan pendekatan kualitatif. Adapaun teknik pengumpulan yang digunakan dalam penelitian adalah observasi, dokumentasi, dan wawancara. Metode analisis data yaitu menggunakan tahap-tahap yang dimulai dari pengumpulan data, reduksi data, penyajian data, dan penarikan simpulan. Penelitian ini dilakukan di sekolah TK Tunas Rimba Margomulyo Bojonegoro. Penelitian dilakukan di tempat tersebut karena identifikasi awal terdapat beberapa anak yang berperilaku belum mampu mengendalikan sosial emosionalnya. Narasumber berasal dari pihak lembaga, orang tua serta masyarakat sekitar.

\section{HASIL DAN PEMBAHASAN Hasil}

Berdasarkan wawancara, anak cenderung meluapkan emosi secara berlebihan. Jika sedang marah anak biasa melempar barang yang ada di dekatnya, menangis sambil teriak-teriak bahkan sampai kencing di celana, serta menyakiti pendampingya. Hal ini diperkuat oleh narasumber dari pihak guru, yang menyatakan bahwa anak jika dalam keadaan marah melakukan perbuatan yang kurang baik melempar seperti alat tulis pada saat kegiatan belajar mengajar. Berdasarkan wawancara, pihak keluarga, anak yang memiliki sisi emosi yang berlebihan cenderung tidak mendapatkan perhatian yang cukup dari seorang ayah. Sosok ayah yang seringkali meninggalkan anak menjadikan pengasuhan yang tidak maksimal karena hanya sosok ibu yang menjadi sosok utama.

\section{Pembahasan}

\section{A. Problematika Yang Dihadapi Anak}

Anak cenderung meluapkan emosi secara berlebihan karena kurang kasih sayang dari seorang ayah. Peran seorang 
ayah dalam mendidik anak sangat mempengaruhi perkembangan anak baik kognitif ataupun emosi anak. Ketika seorang ayah memberikan perhatian dan kasih sayang kepada anaknya, anak akan merasa senang dan gembira bersama ayahnya, sehingga dapat menumbuhkan emosi yang positif. Apabila emosi positif terus dikembangkan dan distimulasi maka kemampuan dalam mengendalikan emosi anak akan baik. Perkembangangan emosi merupakan hal yang terpenting karena di dalam perkembangan emosi ini sangat diharapkan untuk mengelola emosi yang baik sehingga apabila emosi baik yang berkembang maka akan berpengaruh terhadap sikap dan menimbulkan perilaku yang positif. (Qodariah \& Pebriani, 2016). Berbeda dengan seorang ayah yang tidak tahu dengan perannya sebagai ayah misalnya ayah yang memberikan permainan gawai kepada anaknya agar anaknya tidak menggagunya saat berkerja. Hal ini menujukkan ayah yang tidak memberikan kasih sayang terhadap anaknya karena ia membiarkan masa-masa emasnya terkubur dengan teknologi seperti gawai. Hal ini akan mengakibatkan pengaturan di dalam diri anak tidak akan berkembang dan berpengaruh terhadap emosi anak. Seorang ayah harus memberikan waktu yang luang terhadap anaknya sehinga anak akan merasa gembira dan senang. Pengaturan diri merupakan sebuah pengendalian terhadap anak dalam berperilaku sehingga melibatkan seluruh aspek perkembangan pada anak baik emosi, kognitif ataupun sosial.(Widiastuti, 2016). Namun hasil kajian menunjukkan bahwa peran ayah jarak jauh/LDR dalam pengasuhan (komunikasi, kegiatan Bersama, tanggung jawab) terhadap perkembangan emosi anak usai 6 tahun tetap tumbuh secara sehat dan wajar. Saran untuk ayah LDR, agar bisa memaksimalkan waktu bersama anak khususnya bermain yang menjadi dunia anak usia dini, karena tidak selamanya ayah dapat memberikan fasilitas-fasilitas yang selalu diinginkan anak (Wijayanti, 2018).

\section{B. Keadaan Keluarga Anak}

Keluarga merupakan kelompok sosial yang utama tempat anak belajar menjadi manusia sosial (Gerungan, 2010). Dari keluarga pula anak pertama kali mulai belajar berinteraksi sosial. Anak memperoleh pembekalan untuk menjadi anggota masyarakat yang berharga kelak. Ketahanan keluarga menjadi salah satu kunci kundusifitasnya komunikasi dalam keluarga dan berpotensi dapat meningkatkan literasi anggota keluarga (Laksono et al., 2019). Sedangkan apabila hubungan antara orang tua dan anak kurang baik, maka besar kemungkinan bahwa interaksi sosial pada umumnya berlangsung kurang baik pula karena di dalam keluarga berlaku norma-norma kehidupan keluarga. Dengan demikian keluarga memegang peran penting dalam menentukan perilaku kehidupan budaya anak, baik dalam proses pendidikan dan perkembangan kepribadian seorang anak. Norma dalam bermasyarakat dan sosialisasi anak lebih banyak ditentukan dan diarahkan oleh keluarga. Keluarga adalah suatu lembaga yang pertama dan utama dalam melaksanakan proses sosialisasi pribadi anak atau memanusiakan anak. Disinilah anak belajar melakukan adaptasi terhadap lingkungan sosialnya, sehingga anak mulai mengenal makna cinta kasih,simpati, loyalitas, ideologi, bimbingan dan pendidikan. Karena itu keluarga memberikan pengaruh penentu pada 
pembentukan watak dan kepribadian anak (Menurut Kartono, 1997). Dalam hal ini orang tua seharusnya mampu membimbing anak ke hal yang positif dan mempertimbangkan apa yang dilakukan jika itu berpengaruh terhadap perkembangan anak.

\section{Keadaan Lingkungan Anak}

Orang di lingkungan sekitar rumah sangat baik dan sopan begitu juga keadaaan di lingkungan sekolah, Anak mampu bergaul pada teman-temannya dengan baik. Menurut peneliti emosi yang belebihan pada anak bukan disebabkan karena faktor lingkungan namun murni dari diri sendiri dan keluarga. Karakter adalah sebagai panduan dari pada segala tabiat manusia yang bersifat tetap, sehingga menjadi tanda yang khusus untuk membedakan orang yang satu dengan yang lain (Zubaedi, 2012). Karakter yaitu cara berfikir dan berperilaku seseorang yang menjadi ciri khas dari tiap individu untuk hidup dan bekerjasama, baik dalam keluarga, masyarakat dan Negara (Suyanto dan Masnur Muslich, 2011). Berdasarkan beberapa pengertian di atas, dapat dimaknai bahwa karakter adalah ciri khas seseorang dalam berperilaku yang membedakan dirinya dengan orang lain. Pengertian karakter, watak, kepribadian (personality), dan individu (individuality) memang sering tertukar dalam penggunaanya. Hal ini karena istilah tersebut memang memiliki kesamaan yakni sesuatu yang asli dalam diri individu seseorang yang cenderung menetap secara permanen. Berdasarkan kajian peneliti sebaiknya guru atau orang tua lebih memperhatikan anak, memberi pengertian ketika melakukan kesalahan, dan memberikan kasih sayang, dengan begitu anak akan merasa lebih dekat dengan ibu atau guru dan akan mersa nyaman.

\section{PENUTUP \\ Simpulan}

Kecerdasan emosi anak usia dini adalah kemampuan untuk mengenali, mengolah, dan mengontrol emosi agar anak mampu merespon secara positif setiap kondisi yang merangsang munculnya emosi-emosi. Dengan mengajari anak-anak keterampilan emosi anak-anak akan lebih mampu mengatasi berbagai masalah yang timbul selama proses perkembangannya menuju manusia dewasa. Untuk mewujudkan itu peran ayah sangat penting dalam mendidik anak. Seorang ayah harus merawat dan menjaga ketika di dalam kandungan bukan saja ketika anak sudah lahir ataupun dewasa. Peran seorang ayah dalam mendidik anak sangat mempengaruhi perkembangan anak baik kognitif ataupun emosi anak. Ketika seorang ayah memberikan perhatian dan kasih sayang kepada anaknya, anak akan merasa senang dan gembira bersama ayahnya. Sehingga dapat menumbuhkan emosi yang positif. Apabila emosi positif terus dikembangkan dan distimulasi maka kemampuan dalam mengendalikan emosi anak akan baik.

\section{Saran}

Sebaiknya orang tua terlebih ayah harus menjadikan anak sebagai prioritas utama yaitu meluangkan waktu untuk menemani anaknya saat bermain bahkan mendengarkan curhatanya, karena anak akan merasa senang apabila bisa bermain dengan ayahnya, sehingga emosi yang muncul dalam diri anak adalah emosi positif. Saran kepada guru lebih memperhatikan anak tersebut, sehingga 
anak tersebut merasa diperhatikan dan nyaman.

\section{DAFTAR PUSTAKA}

Agus Efendi. (2005). Revolusi Kecerdasan Abad 21. Bandung : Alfabeta

Anthony Dio Martin, 2003. Emotional Qualty Management Cetakan

kedua, Arga: Jakarta

Ardy, Wiyani Novan. 2014. Psikologi Perkembangan Anak Usia Dini. Yogyakarta: Gavamedia

Bachtiar Ibrahim, (2009), Rencana dan Estimate Real of Cost, Jakarta : Bumi Aksara

Casmini. 2007. Emotional Parenting. Yogyakarta : Pilar Medika.

Gerungan. 2010. Psikologi social. (Bandung: PT Refika Aditama), hal. 202

Goleman, Daniel. 2005. Working with Emotional Intilegence: Kecerdasan Emosional Untuk Mencapai

Puncak Prestasi. Jakarta : PT. Gramedia Pustaka Utama

Kartini, Kartono. 1997. Psyicology Wanita, Wanita Sebagai Ibu dan Anak. Jakarta: CV Rajawali hal.250

Laksono, B. A., Supriyono, \& Wahyuni, S. (2019). Tinjauan Literasi Finansial dan Digital pada Tingkat Ketahanan Keluarga Pekerja Migran Indonesia. Jurnal Penelitian Kesejahteraan Sosial, 18(2), 123-134.

Marsudi, L. 2003. Psikologi Pendidikan dan Pendidikan. Malang: UNM Press.

Mashar, Riana. (2011). Emosi Anak Usia Dini dan Strategi Pengembangan. Jakarta: Kencana

Masnur Muslich. 2011. Pendidikan Karakter Menjawab Tantangan Krisis Multidimensional. Jakarta:Bumi Aksara. h. 70

Qodariah , L., \& Pebriani, L. V. 2016 Recognizing Young Children's Exsprecive Styles Of Emotions (2-6 Years Old). Proceeding of The $3^{\text {Rd }}$ International Coference on Early
Childhood Education (Icece 2016), 58

Sagala, Saiful, 2010. Kosep dan Makna Pembelajaran. Alfabeta : Bandung

Shapiro. 2001. Mengajarkan Emotional Intelligence Pada Anak. Jakarta : Gramedia Pustaka Utama

Ulutas, I. \& Omeroglu, E. 2007. "The Effect of Emotional Intelligence Education Program on Emotional Intelligence of Children". Social Bhfior and Personality. 35(10), 1365- 1372.

Widiastutik, A. A. 2016. Presschoolers Self-Regulation And Their Early School successs. Proosedings of $3 R d$ International Conference on Early Childhood Education (Icece 2016), 58

Wijayanti, A. (2018). Peran Pengasuhan Ayah Terhadap Perkembangan Emosi Anak. Seminar Nasional Dan Call for Paper "Membangun Sinergitas Keluarga Dan Sekolah Menuju PAUD Berkualitas, 23-26. http://eprints.uad.ac.id/13030/

Zubaedi. 2012. Desain Pendidikan Karakter Konsepsi dan Aplikasinya dalam Dunia Pendidikan. Jakarta : Kencana. h.9 